\title{
Pelatihan Pembuatan Google Formbagi Guru SD Sebagai Media Evaluasi Pembelajaran Jarak Jauh (PJJ) Masa Pandemi
}

\author{
Rifky Maulana Yusron ${ }^{1}$, Rica Wijayanti ${ }^{2}$, Anindita Trinura Novitasari ${ }^{3}$ \\ ${ }^{1}$ Prodi Teknik Mesin, Fakultas Teknik, Universitas Trunojoyo Madura \\ ${ }^{2}$ Prodi Pendidikan Matematika, STKIP PGRI Bangkalan \\ ${ }^{3}$ Prodi Pendidikan Ekonomi, STKIP PGRI Bangkalan \\ rifky.myusron@trunojoyo.ac.id \\ ${ }^{2}$ ricawijayanti@stkippgri-bkl.ac.id \\ 3aninditatrinura2015@stkippgri-bkl.ac.id
}

\begin{abstract}
ABSTRAK
Pembelajaran Jarak Jauh (PJJ) mulai diterapkan oleh seluruh guru di Indonesia selama masa pandemi covid termasuk guru yang mangajar di tingkat Sekolah Dasar (SD). Aplikasi dari pembelajaran ini tidak semudah yang dibicarakan oleh banyak orang, karena guru harus bisa memilih dan mendesain media pembelajaran dengan menggunakan teknologi. Permasalahan yang dialami oleh guru khususnya di daerah adalah minimnya pengetahuan dalam membuat media pembelajaran berbasis teknologi khususnya media pembelajaran yang dapat digunakan sebagai bahan evaluasi Pembelajaran Jarak Jauh (PJJ). Sebagai solusi untuk mengatasi masalah tersebut, maka tim kami mengadakan pelatihan pembuatan googleformbagi guru SD sebagai media evaluasi Pembelajaran Jarak Jauh (PJJ) masa pandemi. Metode yang kami berikan pada kegiatan pengabdian kepada masyarakat ini adalah dengan cara memberikan pelatihan secara langsung pada guru-guru SD, membuatkan modul sederhana, dan memberikan pendampingan dalam pembuatan media evaluasi googleform. Hasil dari kegiatan pengabdian ini adalah guru-guru yang ikut pelatihan sebanyak 20 orang sudah dapat membuat serta mendesain sendiri googleformsesuai kebutuhan masing-masing mata pelajaran sebagai media evaluasi Pembelajaran Jarak Jauh (PJJ). Selain itu, berdasarkan hasil angket yang diisi oleh guru-guru yang mengikuti pelatihan menunjukkan bahwa $90 \%$ guru-guru paham dalam membuat googleformsendiri dan 100\% guru-guru senang dengan kegiatan pelatihan
\end{abstract}

Kata kunci: googleform, pjj, media evaluasi pembelajaran

\section{ABSTRACT}

Distance Learning (PJJ) began to be applied by all teachers in Indonesia during the Covid Pandemic including teacher who taught at the Elementary School (SD) level. The application of this learning is not as easy as what many people talk about, because teachers must be able to select and design instrucctional media using technology. The problem ezperienced by teacher, especially in theregions, is the lack of knowledge in making technology-based learning media, especially learning media that can be used as anevaluation material for Distance Learning (PJJ). As a solution to this problem, our team conducted training on making google form for elementary teachers as a medium for evauating Distance Learning (PJJ) during the pandemic. The method we provide for this community service activity is by providing direct training to elementary school teachers, making simole modules, and providing assitance in making google form evaluation media. The result of this services activity is that as many as 20 teachers who participated in thetraining were able to create and design their own google form according to the need sofe ach subject as a media for evaluation of Distance Learing (PJJ. In addition, based on the results of the question refilled out by the teachers who attended the training, its hows that $90 \%$ of the teachers under stand how to make google forms them selves and 100\% of the teachers are happy with the training acivities that have been held.

Keywords: googleform, pjj, evaluation learning 


\section{PENDAHULUAN}

Serangan virus covid-19 membawa banyak perubahan dalam segala bidang di dunia khususnya di Indonesia. Bidang yang mengalami perubahan cukup signifikan di Indonesia adalah bidang pendidikan. Proses pembelajaran yang secara rutin biasa dilakukan melalui tatap muka secara langsung beralih menjadi proses pembelajaran daring atau berbasis online yang lebih dikenal dengan Pembelajaran Jarak Jauh (PJJ). Adanya perubahan ini menimbulkan banyak permasalahan di masyarakat kita yang belum menguasai secara mendalam tentang teknologi. Teknologi yang biasanya hanya digunakan sebagai kebutuhan media komunikasi dan hiburan sudah harus bertambah fungsi menjadi media pembelajaran.

Sekolah dengan fasilitas yang sederhana dan sumber daya pengajar yang memiliki kemampuan teknologi sederhana mengalami banyak kesulitan saat penerapan Pembelajaran Jarak Jauh (PJJ). Hal ini juga dialami oleh salah satu sekolah jenjang Sekolah Dasar di Kabupaten Bangkalan yang menjadi mitra kami. Sekolah mitra ini menceritakan kepada tim kami bahwa sedang kesulitan mencari media evaluasi yang tepat dan mudah untuk dibuat serta diaplikasikan pada siswa mereka selama proses Pembelajaran Jarak Jauh (PJJ) berlangsung. Mereka menginginkan setiap guru di sekolah mitra bisa mendesain media evaluasi berbasis teknologi secara mandiri dan siswa juga dapat dengan mudah menggunakan media tersebut.

Berdasarkan permasalahan mitra di atas, maka tim kami sepakat untuk memberikan solusi terhadap mitra yaitu dengan cara memberikan pelatihan dan pendampingan kepada guru yang mengajar di sekolah mitra untuk membuat media evaluasi pembelajaran. Media evaluasi pembelajaran yang tim kami pilih yaitu media google form. Menurut (Purwati \& Nugroho, 2018)google formulir atau google form adalah komponen bagian dari google docs yang disediakan oleh situs Google. Keuntungan dari media ini adalah dapat diakses secara gratis, mudah dalam pengoperasian serta merupakan media yang efektif untuk penilaian.

Selain itu, menurut(Cecilia, Elizabeth,
\& Rebecca, 2017)menganggap bahwa google form sebagai platform netral yang aman untuk digunakan daripada bekerja di platform yang menggunakan perangkat lunak produktivitas berpemilik lainnya. Keefektifan dari media google form sudah tidak diragukan lagi. Hal ini terbukti banyak hasil penelitian yang sudah berhasil menggunakan media ini. Salah satu peneliti yang berhasil menggunakan media google form adalah (Rahardja, Lutfiani, \& Alpansuri, 2018).Hasil penelitian Raharja menunjukkan bahwa google form memiliki manfaat sebagai sistem pendaftaran anggota pada website aptisi.or.id.

Kelebihan media google form sebenarnya sudah dapat dilihat saat pengguna mulai mendesain media ini. Pada google form kita dapat menampilkan tema yang unik dan menarik sesuai dengan kebutuhan kita sehingga pengguna akan lebih senang dan lebih rileks saat mengisi google form. Kelebihan yang kedua yaitu adanya fitur spread sheet. Fitur ini akan mempermudah kita sebagai pembuat google form untuk mengetahui secara detail dan cepat hal-hal yang diiisi oleh responden. Fitur ini bisa kita manfaatkan untuk melihat hasil pengerjaan siswa setelah siswa mngerjakan kuis yang ada di google form. Kelebihan google form yang terakhir yaitu ada banyak pilihan menu kuis yang dapat diedit sesuai kebutuhan sehingga guru dapat dengan leluasa menentukan tipe soal yang akan dijadikan sebagai media evaluasi pembelajaran.

Selain untuk mengatasi permaslahan mitra, program pengabdian kepada masyarakat yang kelompok kami adakan bertujuan untuk mengenalkan pentingnya peran teknologi informsi pada dunia pendidikan. Hal ini sejalan dengan hasil penelitian yang pernah dilakukan oleh(Liantoni, Rosetya, Rizkiana, Farida, \& Hermanto, 2018). Penelitian ini membuktikan bahwa hasil peran teknologi informasi sangat penting untuk peningkatan kemampuan siswa dalam menghadapi era digital sesuai perkembangan zaman. Oleh karena itu, guruguru di sekolah harus mulai mengkolaborasi antara penggunaan model pembelajaran inovatif ddengan media pembelajaran berbasis digital.(Inggriyani, Fazriyah, Hamdani, \& Purbasari, 2020) juga telah mencoba melakukan pendampingan kepada guru-guru 
dengan menggabungkan model pembelajaran inovatif menggunakan kahoot dan hasilnya terjadi peningkatan peningkatan guru terhadap penggunaan model pembelajaran inovatif dengan penggunaan media pembelajaran digital berbasis game.

\section{METODE KEGIATAN}

Kegiatan pengabdian

kepada masyarakat ini dilakukan di salah satu Sekolah Dasar Kabupaten Bangkalan Provinsi Jawa Timur. Kegiatan ini diikuti oleh 20 orang guru yang mengajar di sekolah tersebut dengan berbagai multidisiplin ilmu. Proses kegiatan pengabdian ini dilakukan selama 1 bulan. Bentuk dari kegiatan pengabdian ini adalah pelatihan yang diikuti proses pendampingan secara berkala hingga menghasilkan produk berupa google form sebagai media evaluasi Pembelajaran Jarak Jauh (PJJ)

Metode yang digunakan dalam kegiatan ini ada 3 yaitu pemberian pelatihan secara langsung, pendampingan, serta pengisian angket responden. Metode pertama yaitu pemberian pelatihan secara langsung kepada seluruh peserta pelatihan. Sebelum pelaksanaan tahap pertama ini dilakukan, tim kami sudah melakukan analisis kebutuhan mitra kemudian dari hasil analisis tersebut, kami membuat sebuah rancangan pelatihan yang disertai dengan pembuatan modul sederhana bagi para peserta pelatihan sehingga peserta lebih mudah mengikuti proses pelatihan. Pada pelaksanaan metode perrtama ini kami meminta seluruh peserta pelatihan untuk membawa laptop dan soal yang akan dibuat sebagai evaluasi pembelajaran pada media google form.

Selanjutnya, setelah metode pertama dilakukan kami memberikan waktu selama 2 minggu untuk mencoba membuat media google form secara mandiri. Proses pembuatan media ini walaupun dilakukan secara mandiri, naun kami tetap memberikan pendampingan dan memfasilitasi peserta untuk bertanya dan konsultasi jika ada kesulitan saat proses pembuatan media evaluasi pembelajarn dilakukan.

Metode terakhir dalam program pengabdian kepada masyarakat ini adalah metode pengisian angket responden. Angket responden yang kami buat juga menggunakan google form. Metode ini kami lakukan untuk mengatahuirespon dari para peserta pelatihan tentang kegiatan pengabdian yanga telah tim kami lakukan. Hasil dari responden ini akan tim kami gunakan sebagai evaluasi dan masukan untuk melakukan kegiatan pengabdian kepada masyarakat selanjutnya.

\section{HASIL \& PEMBAHASAN}

Kegiatan pengabdian ini diawali dengan analisis kebutuhan mitra di lapangan. Berdasarkan hasil analisis kebutuhan mitra yang kami dapatkan dari hasil wawancara dengan pihak mitra, maka diperoleh beberapa infromasi. Informasi yang kami dapatkan dari mitra yaitu tentang kendala yang dialami oleh mitra ketika melaksanakan proses Pembelajaran Jarak Jauh (PJJ) pada masa pandemi saat ini. Mitra mengalami kesulitan untuk membuat media evaluasi terhadap hasil dari proses Pembelajaran Jarak Jauh (PJJ. Hal ini dikarenakan sumber daya manusia yaitu guru-guru yang mengajar di sekolah mitra belum memiliki banyak pengetahuan tentang pengembangan media pembelajaran berbasis teknologi. Selain itu, siswa di sekolah mitra juga masih kategori anak-anak yang juga masih belum banyak mengenal media pembelajaran online.

Oleh karena itu, ketika tim kamii mendatangi sekolah mitra sangat meminta bantuan tim kami untuk diadakan pelatihan tentang pembuatan media evaluasi pembelajaran sederhana yang dapat dengan mudah dibuat dan digunakan oleh guru dan siswa. Hasil analisis kebutuhan mitra kami pelajari, kemudian kami mencarikan solusi yaitu dengan mengadakan pelatihan pembuatan google form bagi guru-guru di sekolah mitra sebagai media Pembelajaran Jarak Jauh (PJJ). Kegiatan pengabdian kepada masyarakat ini kami bagi menjadi 3 tahapan.

Tahap pertama dari kegiatan ini adalah pemberian pelatihan secara langsung kepada guru-guru di sekolah mitra. Pada tahap pemberian pelatihan ini kami menyediakan sebuah modul untuk masing-masing peserta yang berisi tentang pengantar google form, tujuan pembuatan google form, dan cara pembuatan google form. Berikut ini adalah contoh dari modul yang kami bagikan ke setiap peserta. 
MODUL

PELATIHAN PEMBUATAN $\mathcal{M E D I A ~}$ EVALUASI

"GOOGLE FORM"

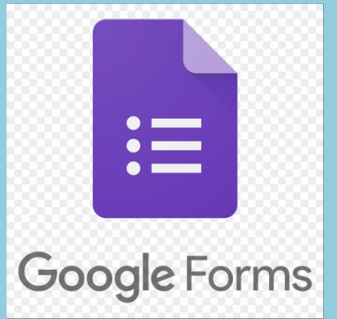

DISUSUN OLEH

R. A. RICA WIJAYANTI, S.Pd.M.Pd. RIFKY MAULANA YUSRON, M.T ANINDITA TRINURA N, M.Pd. 2020

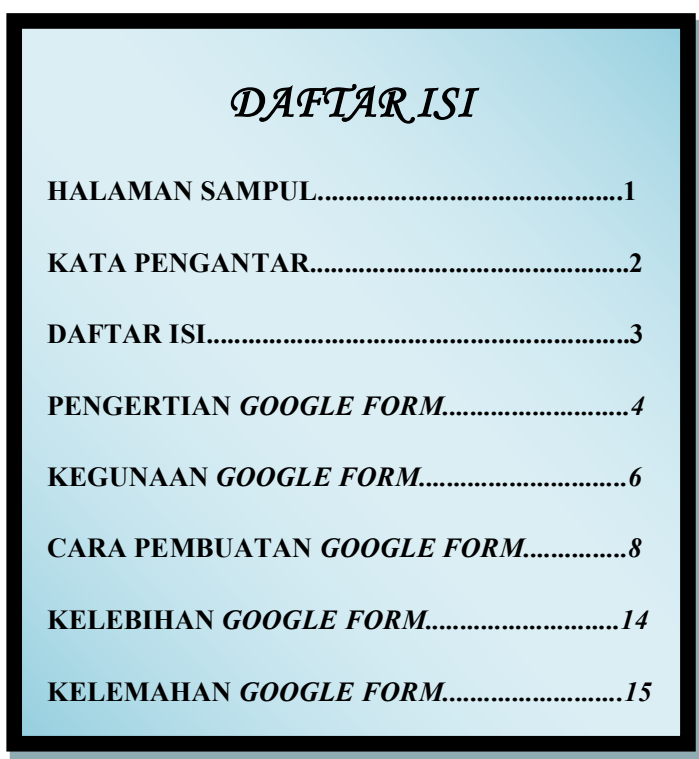

Gambar 2 Daftar isi modul googleform Setelah masing-masing peserta mendapatkan modul kemudian kami menjelaskan isi modull dan diiringi dengan praktek secara langsung oleh tim kami yang diikuti oleh para peserta pelatihan. Peserta pelatihan yang hadir sebanyak 20 orang. Kegiatan pelatihan berlangsung selama 3 jam. Di akhir pelatihan kami menugaskan setiap peserta untuk mencoba paling tidak satu googleform disesuaikan dengan bidang studi yang dajarkan oleh masing-masing peserta.
Setelah tahap pertama selesai kami lakukan, kemudian kami memasuki tahap kedua yaitu tahap pendampingan kepada setiap guru-guru yang telah mengikuti proses pelatihan. Proses pendampingan dilakukan selama 2 minggu. Tim kami membagi 20 peserta pelatihan ke dalam 3 kelompok pendampingan. Setiap kelompok akan mendapatkan 1 orang pendamping dari tim kami. Proses pendampingan bertujuan untuk memfasilitasi peserta pelatihan yang masih bingung dalam membuat googleformyang kami tugaskan pada akhir tahap pertama kegiatan pengabdian kepada masyarakat. Berikut ini adalah salah satu contoh tampilan googleformyang sudah berhasil dibuat oleh salah satu peserta yang merupakan guru bidang studi agama islam.

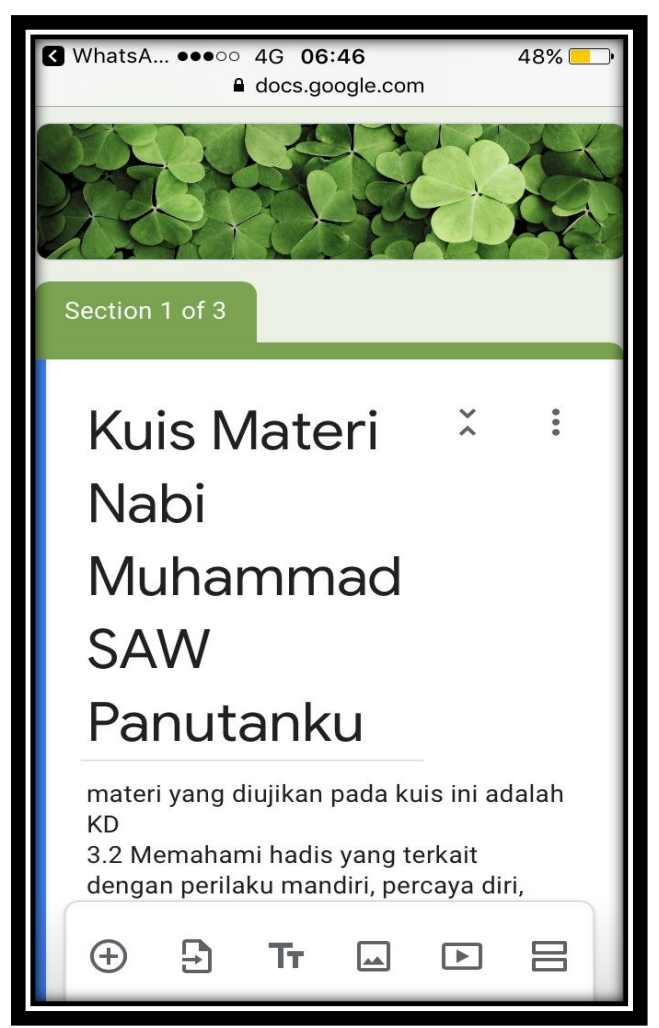

Gambar 3. Tampilan awal googleform 


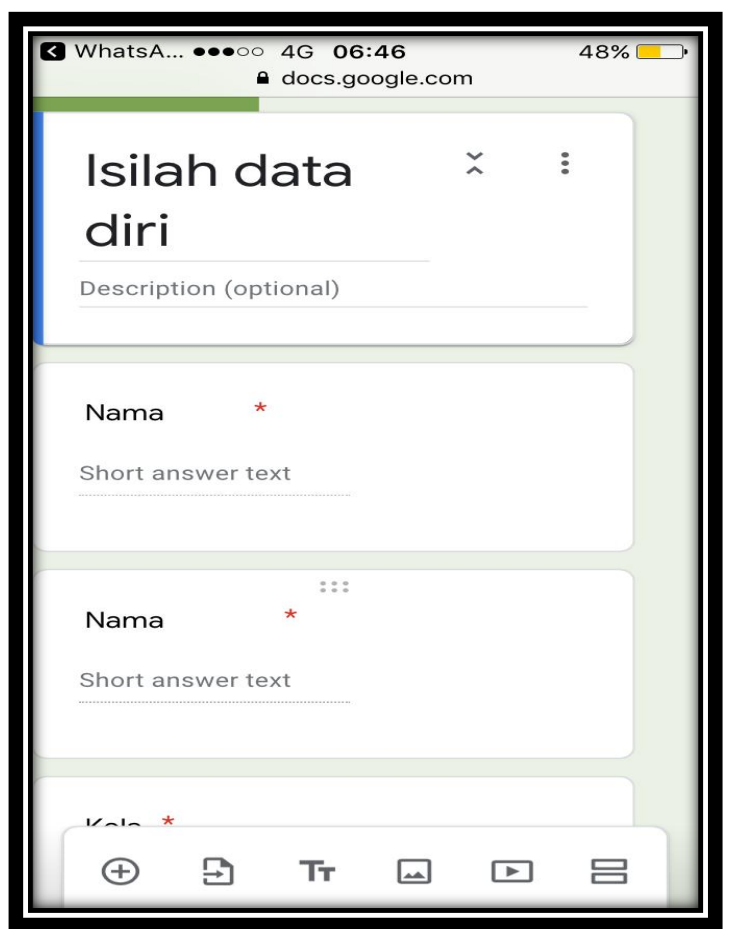

Gambar 4. Tampilan identitas sebelum

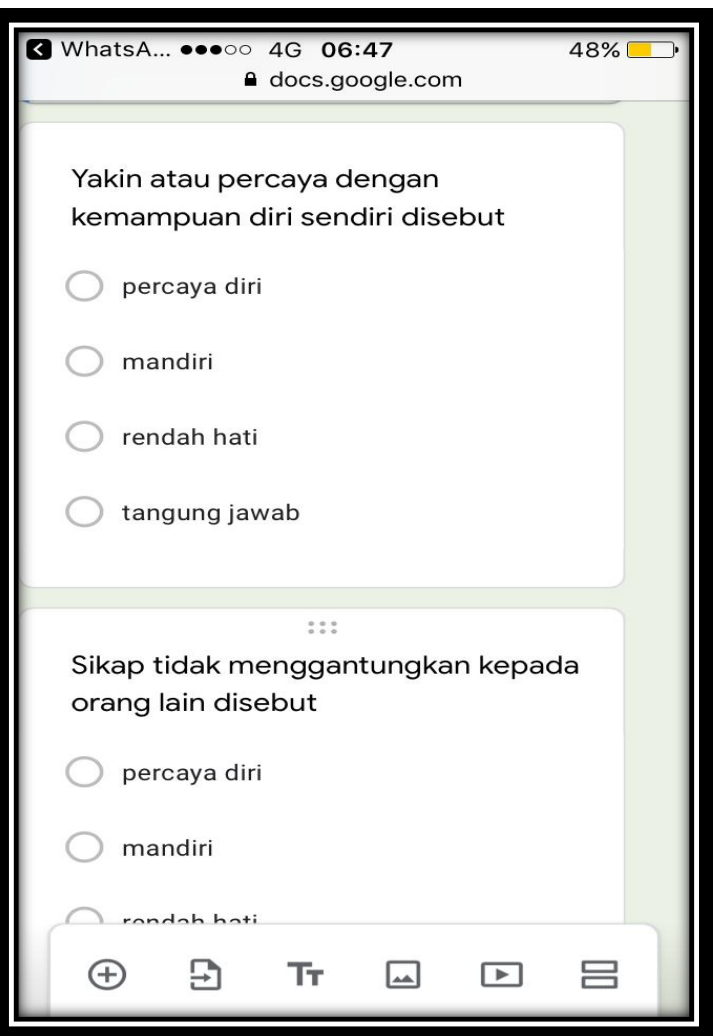

Gambar 5. Tampilan soal pada googleform

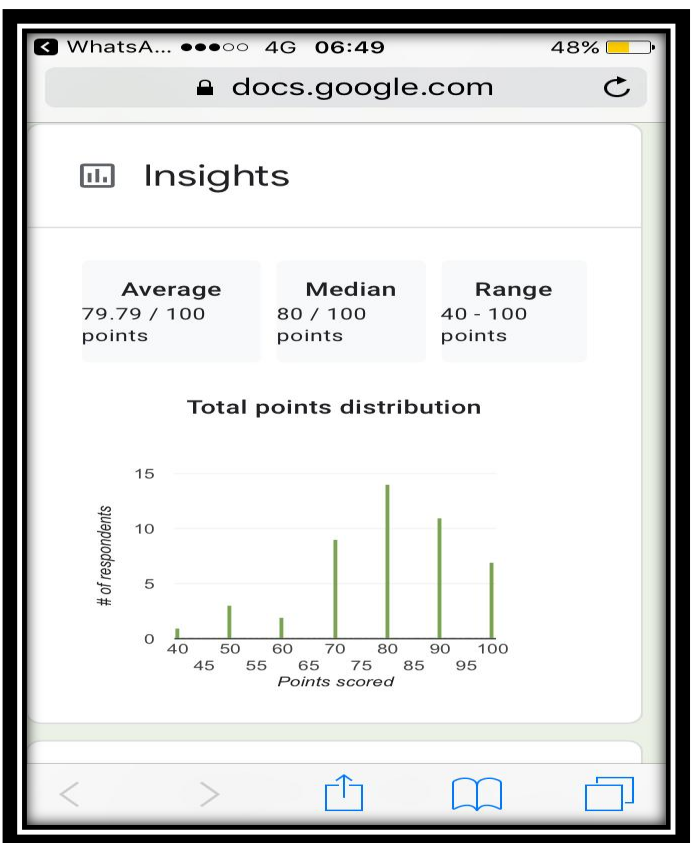

Gambar 6. Tampilan penilaian googleform

Setelah proses pendampingan dilakukan oleh tim kami dan setiap peserta pelatihan sudah menghasilkan minimal sebuah media evaluasi berbentuk googleform dengan baik dan bisa diakses oleh siswa selanjutnya kami masuk ke tahap terakhir dari program pengabdian kepada masyarakat yaitu tahap pengisian angket responden yang harus diisi oleh seluruh peserta pelatihan. Peserta mengisi angket responden melalui googleform yang kami buat. Berikut ini adalah hasil persentase dari angket responden yang sudah diisi oleh peserta.

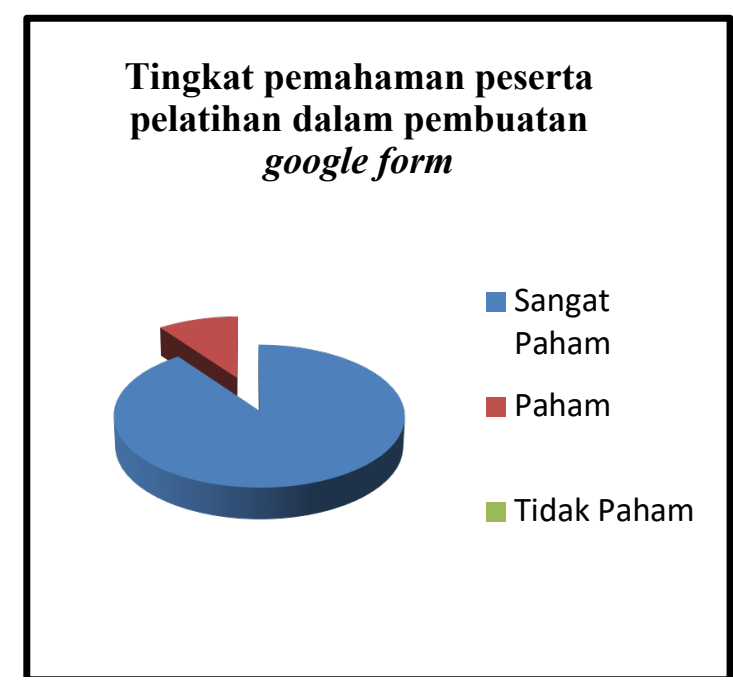

Gambar 7. Diagram tingkat pemahaman peserta pelatihan dalam membuat googleform 


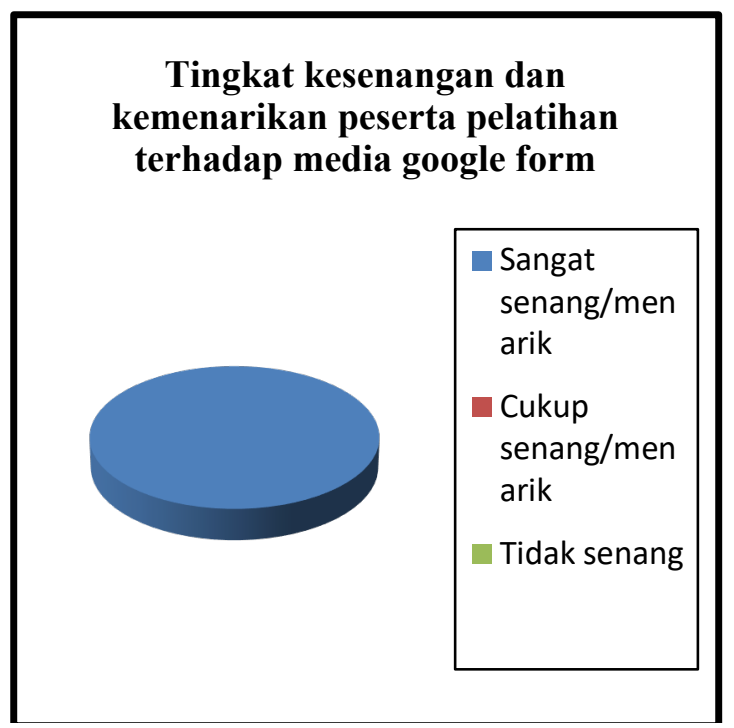

Gambar 8. Diagram tingkat kesenangan dan

kemenarikan peserta pelatihan

dalam membuat googleform

Berdasarkan hasil kegiatan dari pengabdian kepada masyarakat ini menunjukkan bahwa kegiatan pelatihan yang diikuti dengan kegiatan pendampingan pada guru-guru di sekolah mitra telah mencapai hasil yang maksimal. Hal ini terbukti setiap peserta pelatihan sudah bisa membuat googleformsecara mandiri sesuai kebutuhan. Selain itu, keberhasilan kegiatan ini juga ditunjukkan dengan adanya persentase tingkat pemahaman serta kesenangan peserta dalam mengikuti pelatihan tentang pembuatan googleformsebagai media evaluasi pembelajaran.

Sejalan dengan hasil pengabdian ini, hasil penelitian yang pernah dilakukan oleh(Iqbal, Rosramadhana, Amal, \& Rumapea, 2018)juga menunjukkan bahwa penggunaan googleformdapat dijadikan sebagai media pembelajaran. Namun, pada penelitian ini googleformdigunakan sebagai media pemberian tugas kepada mahasiswa bukan sebagai media evaluasi. Penelitian tentang pembuatan googleformini juga pernah dilakukan oleh(Batubara, 2016)yang menunjukkan bahwa googleformdijadikan sebagai media yang cukup efektif untuk menilai kinerja dosen di Program Studi PGMI.

Selain dua hasil penelitian di atas, hasil penelitian yang dilakukan oleh(Fatria, 2018)juga memberikan keefektifan dari penggunaan googleformsebagai media yang digunakan dalam proses pembelajaran. Media ini dapat meningkatkan proses belajar mengajar menjadi aktif dan inovatif sehingga proses pembelajaran berbasis $e$ learningtercapai secara maksimal. Hasil penelitian lainnya tentang googleform juga dilakukan oleh (Handayani, Aini, Cholisoh, \& Agustina, 2018)yang menunjukkan bahwa googleformdapat digunakan sebagai media pendaftaran TOEFL. Sedangkan hasil pelatihan yang pernah dilakukan oleh(Febriadi \& Nasution, 2017) menunjukkan bahwa aplikasi googleform dapat dijadikan sebagai kuisioneronline yang efektif dan terbukti meningkatkan pelayanan kepada masyarakat.

KESIMPULAN \& SARAN
Kesimpulandari hasil kegiatan pengabdian kepada masyarakat ini yaitu (1)adalah guru-guru yang ikut pelatihan sebanyak 20 orang sudah dapat membuat serta mendesain sendiri googleformsesuai kebutuhan masing-masing mata pelajaran sebagai media evaluasi Pembelajaran Jarak Jauh (PJJ); (2) hasil angket yang diisi oleh guru-guru yang mengikuti pelatihan menunjukkan bahwa $90 \%$ guru-guru paham dalam membuat googleformsendiri dan (3) $100 \%$ guru-guru senang dengan kegiatan pelatihan.

Setelah mengetahui hasil dari kegiatan pengabdian kepada masyarakat ini, tim kami ingin memberikan saran kepada guru-guru di sekolah lain yang mengalami permasalahan yang sama dengan mitra kami sebaiknya juga mengundang para ahli di bidang media pembelajaran berbasis teknologi sehingga dapat diadakan pelatihan serta pendampingan. Sedangkan untuk sekolah mitra kami menyarankan sebaiknya diadakan pelatihan lebih dalam lagi untuk guru-guru tentang media pembelajaran berbasis teknologi sehingga kegiatan proses pembelajaran dapat mengikuti perkembangan zaman dengan teknologi yang semakin canggih. Namun, sebelum mengadakan pelatihan tentang media berbasis teknologi sebaiknya pihak sekolah menambah fasilitas wifi di sekolah karena kebanyakan media pembelajaran yang berbasis teknologi menggunakan bantuan internet sehingga jika wifi tidak tersedia atau lemah, maka proses pelatihan juga akan terhambat. 


\section{DAFTAR PUSTAKA}

Batubara, H. H. (2016). Di Prodi Pgmi Uniska Muhammad Arsyad Al Banjari. Universitas Islam Kalimantan MAB, 8(1), 40-50.

Cecilia, K. R., Elizabeth, R., \& Rebecca, C. (2017). Collaborating for metadata creation on digital projects: using Google Forms and Sheets. Library Hi Tech News, 34(8), 20-23. https://doi.org/10.1108/LHTN-08-20170056

Fatria, F. (2018). Penerapan Media Pembelajaran Google Drive Dalam Pembelajaran Bahasa Indonesia. Jurnal Penelitian Pendidikan Bahasa Dan Sastra, 2(1), 138-144. https://doi.org/10.32696/ojs.v2i1.158

Febriadi, B., \& Nasution, N. (2017). Sosialisasi Dan Pelatihan Aplikasi Google Form Sebagai Kuisioner Online Untuk Meningkatkan Kualitas Pelayanan. INOVTEK Polbeng - Seri Informatika, 2(1),

68. https://doi.org/10.35314/isi.v2i1.119

Handayani, I., Aini, Q., Cholisoh, N., \& Agustina, I. I. (2018). Pemanfaatan Google Form Sebagai Pendaftaran TOEFL (Test Of English as a Foreign Language) Secara Online. Jurnal Teknoinfo, $\quad 12(2), \quad 55$. https://doi.org/10.33365/jti.v12i2.73

Inggriyani, F., Fazriyah, N., Hamdani, A. R., \& Purbasari, A. (2020). Pendampingan Model Pembelajaran Inovatif menggunakan Kahoot sebagai Digital Game Based Learning Di KKG Sekolah Dasar. Publikasi Pendidikan, 10(1), 59. https://doi.org/10.26858/publikan.v10i1.1 1992

Iqbal, M., Rosramadhana, R., Amal, B. K., \& Rumapea, M. E. (2018). Penggunaan Google Forms Sebagai Media Pemberian Tugas Mata Kuliah Pengantar Ilmu Sosial. Jupiis: Jurnal Pendidikan IlmuIlmu Sosial, 10(1), 120. https://doi.org/10.24114/jupiis.v10i1.965 2

Liantoni, F., Rosetya, S., Rizkiana, R., Farida, F., \& Hermanto, L. A. (2018). Peran Teknologi Informasi Untuk Peningkatan
Kemampuan Siswa SMA dan SMK Dalam Menghadapi Perkembangan Era Digital. Publikasi Pendidikan, 8(2). https://doi.org/10.26858/publikan.v8i2.56 18

Purwati, D., \& Nugroho, A. N. P. (2018). Pengembangan Media Evaluasi Pembelajaran Sejarah Berbasis Google Formulir Di Sma N 1 Prambanan. ISTORIA: Jurnal Pendidikan Dan Ilmu Sejarah, 14(1). https://doi.org/10.21831/istoria.v14i1.193 98

Rahardja, U., Lutfiani, N., \& Alpansuri, M. S. (2018). Pemanfaatan Google Formulir Sebagai Sistem Pendaftaran Anggota Pada Website Aptisi.or.id. Sisfotenika, $8(2)$, 128. https://doi.org/10.30700/jst.v8i2.401 